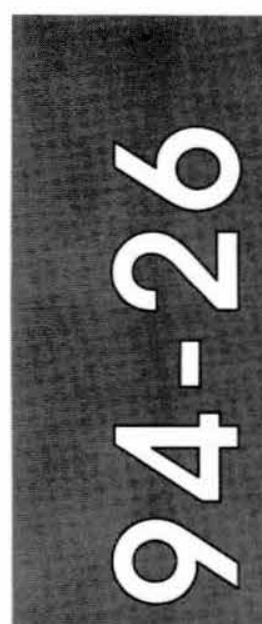

CRREL

Current Issues in

Alaska Wetland Management

Charles H. Racine

August 1994 


\begin{abstract}
Although wetlands cover over half of Alaska, the status, management and regulation of these areas is problematic. The technical literature on Alaskan wetland vegetation, soils and hydrology is abundant, but the application of the literature to wetland management is poorly developed. This report identifies problems, issues and information gaps in the management of Alaskan wetlands. There are numerous arguments and debates on the designation, function and values, and disturbance of certain wetlands in Alaska. Permafrost, fire cycles and unique hydrologic regimes complicate the designation and delineation of Alaskan wetlands. The functions and values of most Alaskan wetlands clearly lie in their importance as habitat, particularly for migrating waterbirds, but an understanding of their role in flood water storage, water quality improvement, subsistence and other functions remains controversial and in need of study. Disturbance and other impacts on Alaskan wetlands is small relative to the large area that wetlands cover and in comparison with the loss of wetlands in the lower 48 states. However, several development projects in Alaska have affected large wetland areas and methods to restore these wetlands are being developed. Cumulative impacts are unknown, as are techniques for restoring permafrost wetlands containing gravel fill.
\end{abstract}

For conversion of SI metric units to U.S./British customary units of measurement consult ASTM Standard E380-89a, Standard Practice for Use of the International System of Units, published by the American Society for Testing and Materials, 1916 Race St., Philadelphia, Pa. 19103. 


\section{Special Report 94-26}

\section{Current Issues in \\ Alaska Wetland Management}

Charles H. Racine 


\section{PREFACE}

This report was prepared by Dr. Charles H. Racine, Research Ecologist, Geological Sciences Branch, Research Division, U.S. Army Cold Regions Research and Engineering Laboratory.

Library personnel were extremely helpful in locating literature: Nancy Liston and Deborah Smith-Cohen at CRREL and Martha Shepherd at the Federal Resource Library in Anchorage. David Cate provided valuable help with editing and final compilation of the report. 


\title{
Current Issues in Alaska Wetland Management
}

\author{
CHARLES H. RACINE
}

\section{INTRODUCTION}

Wetlands are a conspicuous feature of the landscape in northern boreal and arctic regions; only in the High Arctic are wetlands extremely limited (Bliss et al. 1981). They develop in northern areas because the evaporation rate is low relative to precipitation, the drainage is impeded by permafrost, there is extensive development of organic soils and there are contributing geologic factors, such as glaciers, large river systems, extensive coastlines with low coastal plains, and large interior lowland basins. Processes that form and maintain these wetlands include river geomorphic processes, permafrost development and degradation (thermokarst), paludification, rising water tables and patterns of vegetation succession (Drury 1956, Glaser 1987). Well-known wetland types such as bogs, swamps, fens and marshes are well represented in northern regions, describing areas with shallow water or saturated soils that accumulate plant organic materials, which decompose slowly and support a variety of plants and animals adapted to saturated conditions (Mitsch and Gosselink 1986).

All northern wetlands share two common characteristics:

- The water in circumpolar wetlands remains frozen for over half the year; and

- Most of the high solar energy input during the brief summer is used to melt the ice and thaw the snow cover, with little energy to provide the warm soil, air and water that are needed to sustain high rates of biological activity.

Despite the low energy status, polar wetlands are recognized as important breeding habitats for migratory waterbird populations, and they play an important role in the protection of permafrost. Arctic and subarctic wetlands are of increasing concern and importance to regulatory and land management agencies charged with protecting water quality or wildlife potentially affected by the accelerating development of northern oil, gas and mineral resources.
Like other large areas of the circumpolar north, Alaska contains abundant wetlands. They are generally thought to cover almost half the area of the state, or 175 million acres, twice the total areal extent of wetlands in the contiguous United States. Alaskan wetlands span $20^{\circ}$ of latitude and $58^{\circ}$ of longitude and vary widely in origin, substrate and ecosystem properties. They occur in maritime, continental and arctic climates on glaciated and unglaciated terrain and include both coastal and freshwater systems. As Ford and Bedford (1987) stated in their review of the hydrology of Alaskan wetlands, "the geographic extent and enormous diversity of wetland systems within the state simply overwhelm current understanding."

Wetland information is needed by two distinct groups: wetland scientists and wetland managers. While the wetland scientist is interested in wetland processes, structure and classification, wetland managers are concerned with regulations designed to prevent or control wetland modification. Federal protection of wetlands is provided in the Federal Water Pollution Control Act of 1972, commonly called the Clean Water Act. Section 404 of this act requires permits for dredging and filling in waters of the United States (including wetlands).

The management and regulation of wetlands usually requires information for determining first whether a particular site is or is not a "jurisdictional" wetland according to a set of technical criteria based on the vegetation, soil and hydrologic conditions of the site. Once recognized as a wetland, the values and functions of the site are usually determined. It is necessary to know how valuable (relative to other types) a particular wetland is as habitat for moose, birds, fish (anadromous and non-anadromous) and waterfowl, as well as for water quality and hydrologic functions. Finally the impacts or disturbances to the wetland that would result from a proposed project need to be evaluated, followed by an understanding of the methods available to mitigate these impacts. These four areas, therefore, define the needs of wetland managers: 
- Delineation, classification and mapping;

- Functions and values;

- Impacts; and

- Mitigation and restoration.

A fifth subject-legislation and management policy-is beyond the scope of this report.

The purpose of this report is to identify problems and information gaps in the management of Alaskan wetlands. Under each of the four subject areas above, I attempt to identify historical papers, review papers or sources that give an overview in relation to Alaskan wetlands. Then current research trends and issues are described, followed by the identification of knowledge gaps and research needs.

\section{INFORMATION SOURCES}

There is a large amount of literature on wetlands, including vegetation, soils, climate and wildlife, that can to some extent be applied to understanding the management needs for regional wetlands in Alaska. These are generally more useful to a wetland scientist than to a wetlands manager. No single source summarizes knowledge on the wetlands of Alaska similar to a new volume on the wetlands of Canada (National Wetlands Working Group 1988). This regional approach for Canada summarized the literature on wetland types, their development, their values and their human uses. The discussion is greatly facilitated by the use of a National Canadian Wetland Classification system. In contrast with the Cowardin et al. (1979) wetland classification system used in the U.S., terms such as bog, fen, marsh and swamp have been retained.

There is a voluminous body of unpublished "gray" literature that exists for Alaskan wetlands in the form of "in-house" government reports and contract reports by private consulting firms. Many of these articles are not indexed or cataloged in any systematic way and can only be obtained by visiting agency libraries, authors or companies. In Alaska many contract reports have been produced for oil companies operating on the North Slope. It is difficult to access these "proprietary" reports. However, the AEIDC (Arctic Environmental Information Data Center) in Anchorage maintains microfiche, a catalog and an index to the ARCO Arctic Environmental Reports. In addition, the federal Alaska Resource Library (707 C Street, Anchorage) and the U.S. Fish and Wildlife Service Library (Tudor Road, Anchorage) are important sources of unpublished natural resource information for Alaska. A major effort dedicated to reviewing this gray literature is beyond the scope of this project. However, during 1990 these Anchorage libraries were used to review a number of unpublished reports. The literature reviewed here generally covers articles published between 1970 and January 1990.

Federal agencies that have contributed extensively to the Alaskan wetland literature, mostly through unpublished reports of varying availability, include the U.S. Fish and Wildlife Service, the Alaska Department of Fish and Game, the National Oceanic and Atmospheric Administration, the Environmental Protection Agency and the Soil Conservation Service. These agencies have specialized in various aspects of Alaskan wetlands. For example, NOAA funded a multi-year (19721981) Outer Continental Shelf research program, which covers Alaskan coastal wetlands. The U.S. Fish and Wildlife Service has published a series of "community profiles" that present physical, chemical and biological characteristics of wetland ecological communities and may present impact-related information as well (c.f. Hobbie 1984 on Arctic coastal plain tundra ponds). The Army Cold Regions Research and Engineering Laboratories has published reports on riverine wetland processes and permafrost conditions. EPA has funded several studies on developing a cumulative impact assessment for North Slope wetlands. The USDA Soil Conservation Service has mapped hydric soils and wetland vegetation in several areas of Alaska.

The large amount of literature on Alaskan wetlands is the result of several factors:

- The creation of large national parks, forests, preserves, wildlife refuges and state parks, covering at least $50 \%$ of the state. Extensive studies by the agencies responsible for managing their areashave resulted in many published and unpublished reports.

- Oiland gas developmenton the NorthSlope, particularly the construction of the transAlaska pipeline and the Dalton Highway, as well as the development of several large oilfields.

- Other energy-related projects, such as the Susitna hydropower project and the Amchitka and Cape Thompson nuclear projects.

- The presence of several very detailed tundra ecosystem studies conducted as part of the International Biological Program in the 
1970s and more recently by the Department of Energy. These IBP studies are summarized in large books on terrestrial (Brown et al. 1980) and aquatic (Hobbie 1980) ecosystems on the Arctic coastal plain. These Tundra and Taiga Biome studies include multiyear studies at a range of northern sites in North America, Europe and Russia (Bliss et al. 1981). In Alaska IBP sites included wetlands at Barrow and Prudhoe Bay. At least one of these Alaskan IBP studies on the ecology of tundra ponds has been "translated" by Hobbie (1984) into a wetland-oriented approach.

The R4D (Response, Resistance, Resilience and Recovery from Disturbance) program being conducted at Toolik Lake in the northern foothills of the Brooks Range involves process studies and responses to manipulation of both wetland terrestrial and aquatic systems, particularly in terms of nutrient inputs and temperature changes.

Extensive studies of floodplain taiga forests and succession in interior Alaska around Fairbanks have also been published (Van Cleve et al. 1986). Many of these sites represent wetlands, and the literature can be used to help construct an understanding of wetland functions and values, particularly in relation to food chains, primary production and hydrology. However, a review and summary of the conclusions and findings of these detailed ecosystem studies are beyond the scope of this report.

\section{DELINEATION, CLASSIFICATION AND MAPPING}

Soil type and vegetation composition, combined with some knowledge of hydrology, are the basis for the recognition and delineation of wetlands using the Federal manual (Federal Interagency Committee for Wetland Delineation 1989). Many of the general inventory studies of Alaskan vegetation, soils and hydrology fail to distinguish wetland from non-wetland areas (i.e. Lee et al. 1982). However, by using published lists of Alaskan hydrophytic plant species (Reed 1988) and hydric soils (Soil Conservation Service 1985), a decision can sometimes be made if a particular study site is a jurisdictional wetland.

Major coastal wetland areas in Alaska have been identified, such as the Arctic coastal plain, Yukon-Kuskokwim Delta, Copper River Delta, Colville Delta and Upper Cook Inlet areas. Large inland lowlands with extensive wetlands include the Yukon Flats, Tanana Flats and Innoko areas.

Since 1984 the National Wetland Inventory (NWI) conducted by the U.S. Fish and Wildlife Service has been calculating and mapping wetland acreage for Alaska (Hall 1988). As of 1990, wetlands over about $20 \%$ of the state have been mapped at a scale of 1:63,360 by the NWI. These regions include parts of interior Alaska (FairbanksTanana basin and Yukon Flats), southcentral Alaska (Anchorage), southeastern Alaska and the North Slope (Arctic coastal plain). Vegetation, as interpreted on color infrared aerial photos, is the criterion for recognizing wetlands on these maps. The Cowardin et al. (1979) classification system is used to designate the different wetland types. User notes accompanying each of the 1:63,360 quadrangle wetland maps summarize the regional information on hydric soils, vegetation, topography and climate. The NWI classification units are described in terms of dominant species and are cross-referenced to the Viereck et al. (1986) Alaska vegetation classification.

As part of the NWI, acreages have been calculated by region for Alaskan coastal wetlands by Hall (1988). These include marine intertidal, estuarine subtidal, estuarine intertidal nonvegetated and estuarine intertidal vegetated (Cowardin et al 1979 classification units). This survey showed that while Alaska contained about the same acreage of estuarine habitat as the contiguous U.S. (21 million acres), in Alaska a much smaller percentage (1.7\%) of this is estuarine intertidal vegetated wetlands (salt marsh) than in the contiguous U.S. (22.2\%). Southeast Alaska has the smallest acreage of salt marsh; western Alaska has the largest.

Wetland inventories have also been conducted for several municipalities within Alaska, including Anchorage (Racine and Hamilton 1980), Homer (Jorgenson and Berg 1987) and Juneau (Needham and Skordal 1987). The Homer study is a particularly good example of how soil, vegetation and hydrologic information can be combined to delineate wetlands. Regional wetland inventories include studies of Knik Arm (Ritchie et al. 1981), the Kenail lowlands (Rosenberg 1986), the Copper River Delta (Thilenius 1990), the Colville Delta (Meehan and Jennings 1988) and the Tongass Forest (DeMeo and Loggy 1989).

Soils

A wetland or hydric soil is generally defined as a soil that in its undrained condition is saturated, flooded or ponded long enough during the grow- 
ing season to develop anaerobic conditions that favor the growth and regeneration of hydrophytic vegetation (Soil Conservation Service 1985, National Technical Committee for Hydric Soils 1987). In the Wetland Delineation Interagency Manual (Federal Interagency Committee for Wetland Delineation 1989), hydric soils are recognized on the basis of soil morphologic indicators such as gleying and mottling due to saturation and development of reducing (anaerobic) conditions. However, "if the soil conditions are such that free oxygen is present, organic matter is absent, or temperatures are too low (below $41^{\circ} \mathrm{F}$ ) to sustain microbial activity, gleization will not proceed and mottles will not form even though the soil may be saturated for prolonged periods of time" (Diers and Anderson 1984). At many sites in northern Alaska, soil temperatures at depth may never rise above $41^{\circ} \mathrm{F}\left(5^{\circ} \mathrm{C}\right.$, or biological zero), so the concept of a growing season during which the soils are saturated is meaningless. There is a need to understand the effects of these soil temperature regimes on the development of hydric soil indicators.

In addition, wildfire in the discontinuous permafrost areas of interior Alaska may result in soils that alternate between shallowly thawed and therefore waterlogged (late in the fire succession) and more deeply thawed and better drained soils (shortly after fire) (Van Cleve and Viereck 1983). Therefore, soils at the same site could theoretically alternate between hydric and non-hydric conditions.

Soils are not well mapped in Alaska, and recognition of hydric soil series is only beginning by the Soil Conservation Service (1985). The Exploratory Soil Survey of Alaska (Reiger et al. 1979) contains small-scale maps $(1: 250,000)$ and soil classification. Detailed large-scale soil series designations are required for wetland designation. Since the presence of soils containing permafrost is often important to the determination of wetland status, maps showing the distribution of permafrost, information on ice content and the active layer depth are valuable to wetland delineation. Unfortunately maps showing permafrost distribution in Alaska are extremely generalized (Ferrians 1965). Information on permafrost distribution in Alaska can be obtained from literature available in the International Permafrost Conference proceedings and by the Army Cold Regions Research and Engineering Laboratory (CRREL).

\section{Vegetation}

Wetland vegetation generally consists of hydrophytes, or wetland plants adapted to growing in saturated soils or wet conditions. A series of unpublished literature reviews and classification schemes for Alaskan wetland vegetation were written by Batten (1980, 1986), Batten et al. (1978) and Batten and Murray (1982). These are important and useful documents providing a statewide perspective of Alaskan wetland vegetation (including coastal tidal wetlands). However, none of these wetland descriptions include the soil and hydrologic criteria necessary for the recognition of jurisdictional wetlands.

Satellite imagery and aerial photography have been used extensively to produce general vegetation maps of various regions of Alaska (Walker et al. 1982, Swanson 1985, Tande and Jennings 1986, Walker and Acevedo 1987, Talbot and Markon 1988). It is not often possible to determine which map units are jurisdictional wetlands.

In addition, numerous inventories of vegetation have been conducted as part of environmental statements and inventories for federal lands (Racine and Anderson 1979, Rothe et al 1983) and for development projects (Hettinger and Janz 1974, Walker and Webber 1979).

The Cowardin et al. (1979) system of wetland classification is based on vegetation and is being used in the mapping of Alaskan wetlands by the National Wetland Inventory. Mapping is accomplished using color infrared aerial photography at a scale of 1 in. $=1$ mile. This system was developed for the contiguous U.S. for mapping wetlands from aerial photography and to avoid well-known but ambiguous terms such as marsh, bog, swamp and fen. In Alaska, where peaty wetlands predominate, these all fall into one term (palustrine), leaving very little room for the differentiation of classes.

Other classification systems for Alaskan vegetation and landforms have been developed, including a long-term project by the Institute of Northern Forestry (USFS). In the most recent version of the Alaska vegetation classification (Viereck et al. 1986), wetlands are not specifically recognized, although the Aquatic community (plants that are submerged or have floating leaves) and Wet Forb Herbaceous types are clearly wetlands.

Batten (1980) developed an Alaskan wetland classification scheme based on the recognition of five major communities: 1) aquatic, 2) marsh, 3) wet meadow, 4) ericaceous shrub wetland and 5) erect shrub wetland. A marsh has standing water (greater than $15 \mathrm{~cm}$ deep) and is dominated by one of the following species: Arctophila fulva, Equisetum fluviatile, Eleocharis palustris or Scirpus sp. In 
contrast a wet meadow has water depths of less than $15 \mathrm{~cm}$ and is dominated by species of sedge (Carex sp.) or cottongrass (Eriophorum sp.).

Other classification systems of Alaskan wetlands have been developed by waterbird biologists to better designate habitat types (Bergman et al. 1977, Kessel 1979, Derksen et al. 1981, Meehan and Jennings 1988). The Cowardin et al. (1979) wetland classification system is awkward for evaluating the importance of wetlands to waterfowl, and investigators have chosen more general classifications specific to physiographic features and vegetation of local areas (Lensink and Derksen 1986).

Several papers have attempted to show how the various classification systems in use in Alaska are interrelated by cross referencing two or more systems (Rosenberg 1986, Jorgenson and Berg 1987). These are important because they link wetland delineation and recognition to an evaluation of their functions. Meehan and Jennings (1988) developed habitat maps for the Colville River Delta on the arctic coast and compared classification units used by Viereck et al. (1981), Markon (1980) and NWI. A GIS system was used to correlate the bird census data (tundra swan, greater whitefronted goose, yellow-billed loon and pacific loon) and the cover types. Eight habitat classes were recognized and ranked in terms of waterfowl use and correlated with the Markon (1980) and Bergman et al. (1977) wetland cover types.

Tande and Jennings (1986) also developed maps and a vegetation classification for an area in the Yukon Delta National Wildlife Refuge in western Alaska. These vegetation types and landform features will form the basis for determining the amount and quality of goose nesting habitat. The final units were correlated with the NWI units with some problems.

\section{Problems and issues in wetland delineation}

With regard to soils and hydrology, there remains abundant confusion concerning the wetland delineation and designation of saturated soils areas that overlie permafrost. A recent oil company report (Senner 1989) questioned the designation of arctic coastal plain tundra as wetland because of the desert-like low precipitation (less than 5 in. per year) and the dependence on permafrost to trap standing water (i.e. there are no groundwater connections). In interior Alaska there are forested types on fairly steep north-facing slopes underlain by permafrost. Similarly in northern Alaska, soils are often saturated due to impeded drainage by permafrost. Permafrost-induced wetlands in Alaska are analogous to many wetlands on soils with an impervious layer in non-permafrost areas. In southeastern Alaska there is no permafrost, but high precipitation causes soil saturation. Do these conditions require special consideration in terms of wetland designation?

Of particular concern in wetland delineation is the occurrence of several extensive terrain types of unknown wetland status (i.e. they have not been extensively subjected to the criteria in the Interagency Manual). These include tussock tundra, which is by far the most extensive tundra type in Alaska, and open black spruce/moss forest or "muskeg" types. Batten (1980) excluded tussock tundra from his survey of Alaskan wetland types. In Canada the large expanses of tundra covered with tussock-forming graminoid species are not considered wetlands since they are not waterlogged throughout the year (Zoltai and Pollett 1983). This view is in agreement with the definition of tundra bogs in Siberia used by Botch (1974). However, the Interagency delineation manual only requires that surface flooding and soil saturation occur for one week or more during the growing season. Batten (1980) also excluded the following from his Alaskan wetland classification scheme:

- Willow thickets and perennial herb communities on gravel bars flooded annually but dry most of the summer;

- Many coastal types, even though all are probably inundated by tidewater at long intervals (some annually), including the alder fringe at the forest edge, most strand and all dune types, including Elymus types, and some well-drained types at the upper edges of coastal marshes flooded only by storm surges one or a few times annually;

- Steep terrain such as seepage areas on cliffs, bluffs etc;

- Snowbeds; and

- Solifluction lobes, or at least the termini of such lobes.

Alaskan floodplains are dynamic systems in which periodic flooding may produce wetland conditions in areas that were previously levees or sand or gravel bars.

Although vegetation has been mapped and classified over extensive areas of the state and some soil surveys have been conducted, the correspondence between hydrophytic vegetation, hydric soils and hydrology has not been well tested in Alaska (Walker et al. 1989). Therefore the actual designation of a field site as either wetland or non-wetland 
(upland) is often difficult. Although a list of hydrophytic plants (Reed 1988) and a few hydric soils lists are available, there is widespread recognition that Alaskan plant species have broad ecological amplitudes, making it difficult to assign species to a specific segment of the soil moisture gradient. Even a preliminary guide to the site identification and delineation of the wetlands of Alaska(Huffman and Tucker 1984) used only vegetation to identify wetlands in each region of the state and ignored the soil and hydrology criteria entirely.

Two recent studies specifically attempted to delineate wetlands using both vegetation and soil criteria. On the North Slope (foothills region), Walker et al. (1989) tested the correspondence between hydric soils (as defined by Soil Conservation Service 1985) and wetland plant species (as defined for Alaska by Reed 1988). A wetland index using plant species hydrophyte values (obligate to facultative) was calculated for the vegetation occurring on the various hydric soils. In general the correspondence was good, suggesting that vascular plant species lists can be used to distinguish between wetlands and nonwetlands or hydric and nonhydric soils. However, one hydric soil type (Pergelic cryaquept) yielded a borderline index value; it is this soil type and vegetation (moist tussock sedge/dwarf shrub tundra) that is one of the most widespread tundra types in Alaska. This vegetation is rooted in the organic horizon, which frequently drys out later in the summer while the mineral soil remains saturated.

In southeastern Alaska, DeMeo and Loggy (1989) used soils and vegetation to delineate and map forested wetlands in the Tongass National Forest. They modified the vegetation weighting system in the new Interagency manual (based on the percentage of the total number of dominant species that are either obligate, facultative-wet or facultative). They dropped the facultative species and calculated an index for both the upland/ facultative-upland and obligate/facultative-wet using cover.

\section{WETLANDS FUNCTIONS}

Once wetlands have been delineated using hydric soils, hydrophytic vegetation and hydrology criteria, it is important to determine their functions. These define in human terms their values or benefits in terms of water quality, quantity, habitat and recreation. The potential values of wetlands are well known and generally focus on providing habitat for fish and wildlife and maintaining hy- drologic systems and the quality of surface and ground water. The most important value of Alaskan wetlands is generally recognized as related to habitat and food chain functions, with most emphasis placed on migratory waterbirds (including swans, ducks, geese, loons and shorebirds). These arctic and subarctic wetland nesting areas are crucial to maintaining the North American waterfowl population. An annotated bibliography of literature on Alaskan water birds was published by the U.S. Fish and Wildlife Service (Handel et al. 1981). Numerous studies by the U.S. Fish and Wildlife Service, the Alaska Department of Fish and Game and other agencies have documented the wildlife habitat values of many wetland areas in Alaska (Bergman et al. 1977, Ritchie et al. 1981, Hogan and Tande 1983, Rosenberg 1986, Meehan and Jennings 1988). In addition, the functioning of several site-specific arctic wetlands in terms of energy capture, food chains and nutrient cycling has been studied in detail (Brown et al. 1980, Hobbie 1980). However, to translate a function into a value requires a standard of comparison by which to assign some benefit.

The only published document to address wetland functions from a state-wide perspective is the proceedings of a 1986 symposium entitled Alaska: Regional Wetland Functions (edited by Van der Valk and Hall 1986). Papers in this volume cover hydrology (Ford and Bedford), subsistence use (Ellana and Sherrod), waterfowl habitat (Lensink and Derksen) and vegetation (Batten). Human uses of arctic wetlands include both subsistence and sport hunting and fishing, as well as energy development, since much of the oil and gas deposits in Alaska underlie wetlands.

\section{Regional studies of wetland functions and values}

Wetland function and values analyses for at least one or more functions have been conducted in Juneau (Adamus 1987), Anchorage (Hogan and Tande 1983), Seward (Oakley et al. 1987), Knik Arm (Ritchie et al. 1981) and the Kenai lowlands (Rosenberg 1986). Extensive studies of waterbird use and wetland habitat on the North Slope of Alaska also provide a functional evaluation of these wetlands (Lensink and Derksen 1986).

Adamus, who helped develop the wetland evaluation manual for the contiguous U.S., has tested some predictors for Juneau wetlands (Adamus et al. 1987). He considered several wetland functions, including groundwater recharge and discharge, surface hydrologic control, sediment/toxicant retention, nutrient transformation/ 
export, riparian support and salmonid habitat. For each of these functions, both direct measurement and extrapolation from superficial characteristics were used to rate the function (high, moderate or low). Some wetlands were instrumented to measure hydrologic function, while for others indirect criteria were developed to rate the function.

Hogan and Tande (1983) inventoried the vegetation and bird species in 11 palustrine wetlands in the Anchorage Bowl. The highest bird use was in bogs with the greatest open water and interspersed vegetation; however, the greatest bird density was found in small bogs bordering lakes. Another wetland study near Seward (Oakley et al. 1987) showed that wetlands adjacent to Salmon Creek are important to the overall salmonid production in the creek.

Lensink and Derksen (1986) summarized the numbers and density of waterfowl using wetlands in each of the major regions of Alaska. Both coastal and interior areas were included. The coastal habitats of the Yukon Delta are critical to more species or subspecies of waterfowl than any comparable area in North America, while the Yukon Flats in the Interior supports a breeding population density 2-3 times higher than other waterfowl breeding areas in Alaska.

\section{Current issues in Arctic wetlands functions and values: the Senner report}

In a report by Senner (1980) the oil companies have questioned the values of North Slope wetlands and therefore the need for regulatory actions in areas where oilfield development is taking place in Alaska. This report, entitled "Effects of Petroleum Operations in Alaska Wetlands," and a short pamphlet with photos, has many technical problems, yet they were widely distributed.

The Alaska Department of Fish and Game and several conservation groups and federal agencies have critiqued this report (Post 1990). Roger Post of the Alaska Department of Fish and Game reviewed the research literature, concluding that permafrost wetlands on the North Slope perform critical habitat and hydrologic functions that were denied by Senner (1989). This controversy over the functions and values of Alaskan wetlands is an excellent opportunity to understand the Alaska wetlands literature, issues and knowledge gaps in the literature.

The Senner report makes the inference that a wetland needs all functional values (flood storage, habitat, water supply, recreation etc.) to be considered valuable, although the Clean Water Act 404 (b)(l) states, under a list of a possible wetland values, that any one function can be justification for recognizing a particular wetland of high value. In the case of the Arctic, the habitat value of wetlands for shorebirds and waterfowl is the most studied and best understood.

Senner made little or no distinction between the different types of wetland habitats and areas on the North Slope. These areas and habitats have different functions and values and should be considered separately. For example, the Colville River delta is a unique wetland habitat of restricted occurrence along the arctic coastal plain.

\section{Hydrologic values}

Senner argued that arctic wetlands have little or no hydrologic value (flood storage, groundwater recharge/discharge, erosion control/shoreline protection etc). His arguments are based mainly on a paper in a wetlands symposium proceedings by Robertson (1987), entitled "The Arctic Coast: Wetland or Desert," a speculative paper that was not supported by data. Senner argued that arctic wetlands do not regulate spring runoff or store meltwater since they are frozen during spring breakup and only shallowly thawed the rest of the summer. A number of tundra wetland hydrology papers by Woo and Steer (1986) in Canada and Kane et al. (1981) in Alaska show that flow regulation and storage do occur in arctic wetlands by mechanisms such as ice-free voids and cracks, absorption by dehydrated moss and peat, low relief, subsurface flow and thaw pond storage. Watershed discharge data showing high peakflows and low base flows cited by Senner from Ford and Bedford (1987) are from a site in the subarctic rather than arctic. Hobbie (1984) stated that where ponds are abundant in the arctic coastal plain, most of the water that would ordinarily run off in the spring instead goes to fill up the pond basins. Senner argued that because there is evidence of permafrost thaw and erosion along arctic shorelines, the wetlands do not provide erosion control or shoreline protection. However, removal of the surface wetland vegetation cover in the arctic has been shown to result in thermokarst and extensive erosion (Lawson 1986).

\section{Water quality}

Senner argued (again citing Robertson as an authority) that arctic wetlands do not improve water quality by removing sediments, nutrients or pollutants because of the short summers and cold soils leading to low plant productivity and therefore low uptake of nutrients. He argued that the presence of organic soils in which plants are rooted 
and the absence of a mineral soil and sediment layer indicates that nutrient uptake is low. Hobbie (1984) showed that tundra pond wetlands (which cover a significant area of the arctic coastal plain) are reasonably productive and actually contain fine sediments that have high cation exchange and buffering capacity, particularly in relation to phosphate $\left(\mathrm{PO}_{4}\right)$. Other studies by Chapin et al. (1980) show that tundra vegetation is biologically active at low temperatures and rapidly takes up phosphorus and nitrogen in response to fertilization.

\section{Waterbird habitat}

With regard to wildlife in North Slope tundra, Senner supported the "vacant hotel" notion that population regulation occurs off the breeding ground and that the limiting factors are the same for all species. Extensive studies by U.S. Fish and Wildlife biologists, summarized by Meehan, counter this argument, clearly showing that different factors limit the populations of different waterfowl species. For example, the predominant ducks that breed in the Arctic overwinter at sea in northern latitudes. Factors affecting breeding ground productivity (drought and directhabitat loss) have historically been the major determinants of waterfowl populations.

The vacant hotel theory proposed by Senner also conflicts with shorebird territoriality studies by Pitelka et al. (1974). Such territoriality is a strong indication that the habitat is at effective carrying capacity. In addition many waterfowl species that breed in North Slope wetlands are also territorial (oldsquaw, tundra swans and the three species of loons). Another value of arctic wetlands not mentioned by Senner or Post is that they provide "safety nets" for waterfowl such as nonbreeding pintails during drought conditions on the prairies.

\section{Large mammal habitat}

Senner denied that caribou and muskox use wetlands and that their populations are limited by predators and hunting rather than by habitat. Microtine (voles and lemming) habitat values are not discussed, and it is well known that caribou use coastal plain wetlands to escape harassing insects during the summer and as a calving area in the spring. Also, moose and muskox use North Slope riparian wetlands for winter browse and cover.

\footnotetext{
*Personal communication.
}

Knowledge gaps in Alaskan wetland evaluation

The habitat values of North Slope wetlands are well studied for the flat thaw-lake plain region (Bergman et al. 1977). However, less well known are the habitat values of rolling arctic terrain dominated by moist tussock tundra with few thaw lakes. In interior Alaska the values of black spruce muskeg wetlands underlain by permafrost need to be defined (Van Cleve et al. 1986). Although hydrologic and ecologic aspects of black spruce wetlands and treeless bogs have been studied, particularly in relation to fire, permafrost and ecological succession, the functions associated with these wetlands have not been systematically examined. Also, local areas of waterfowl concentrations such as coastal deltas need to be better identified (Meehan 1988).

The hydrologic and water quality functions of Alaskan wetlands are often poorly understood. According to Ford and Bedford (1987) most of the hydrologic information is concentrated for the arctic coastal plain or in the interior near Fairbanks (Kane 1990). Particular information gaps include the hydrology of alluvial wetlands associated with most rivers or the high-elevation wetlands of the southeast coast, the Seward Peninsula and alluvial river valleys (Yukon Flats, Tanana Flats etc.). The hydrologic role of permafrost is poorly understood, as is snowmelt (Woo and Steer 1986). Wetland soils tend to have a high ice content during snowmelt and thus probably do not contribute significantly either to flood storage or to groundwater recharge. Several site-specific wetland hydrology studies have been conducted in Anchorage (Glass 1986) and Juneau (Adamus et al. 1987), which show to what extent certain palustrine wetlands store water and perform recharge-discharge functions.

Ellanna and Sherrod (1986) argued that since subsistence-based socioeconomic and cultural systems are extremely dependent on wetlands throughout rural Alaska, any wetland evaluation system should include this function and value.

Another area of deficiency in Alaska wetland evaluation is the existence of a rapid methodology for evaluating wetlands. Such a technique has been developed for the continental U.S. using predictors (Adamus et al. 1987). However, the 1986 symposium (Van der Valk and Hall 1986) clearly suggested that existing techniques for evaluating wetlands in the contiguous U.S. are not applicable to Alaskan wetlands and in particular to those underlain by permafrost. 
Predictors for waterfowl habitat values may also be different in Alaska from those developed for the contiguous U.S., where wetlands that are connected to another water body such as a lake or river had the highest waterfowl habitat values. In Alaska, Lensink and Derksen (1986) found that closed-basin lakes in which water levels varied drastically had the highest productivity. They suggested that variation in water levels encourages the grow th of emergent vegetation and the decomposition of accumulated organic sediments, particularly in closed-basin wetlands (not connected to a river). This leads to higher levels of nutrients (nitrogen and phosphate), resulting in higher wetland productivity, as indicated by the abundance of emergent vegetation. Lynch (1940) associated wetlands of high productivity in the Mackenzie Delta to early successional floodplain lakes and wetlands where alluviation (flooding) occurs on a periodic basis. However, Murphy et al. (1984) found that wetlands in the Tanana valley that were connected to rivers had the highest productivity (and more stable water levels).

\section{DISTURBANCES AND IMPACTS TO ALASKAN WETLANDS}

Historically the uses of Alaskan wetlands have involved a wide range of activities, including energy development (hydroelectric, peat mining, oil/ gas), mining for metals, agriculture and logging. Impacts result from the exploration and prospecting for resources as well as the actual development. Other impacts include municipality development or construction of roads and buildings, pipelines and powerline projects, as well as the use of off-road vehicles. The major impacts to arctic and subarctic wetlands in Alaska are presently related to the discovery and development of oil and natural gas.

The 1983 Office of Technology Assessment Alaska Case Study (Marcus 1983) provided an excellent overview of impacts in wetlands representing the seven regions of Alaska. While oil and gas exploration and development has proceeded in the North Slope region for many years, mineral extraction and accompanying road development is planned on a large scale in many other wetland areas of the state. Marcus (1983) first described the wetland acreage and uses in each region of the state. He then described the wetland regulatory framework in terms of the various federal and state laws and regulations that apply to wetland use: Included is a discussion of the role of each agency in relation to the various laws. The Corps Section 404 permit is considered to be the only program with statewide applicability for regulating the filling of wetlands in Alaska. However, the disposal of spoils from placer mining in wetland and streambed areas appears to be unregulated by the Corps.

Senner (1989) argued that Alaska has lost only $0.05 \%$ of its wetlands up to 1989 . This statistic lumps all the wetlands of Alaska into a single category, ignoring the important qualitative differences and importance of particular wetland ecosystems. The percentage of wetlands lost in Alaska is locally high (greater than $50 \%$ ), particularly within municipalities such as Anchorage, Fairbanks, Juneau, Seward and Homer.

The literature on impacts of oil development to Alaskan wetlands is contained in reports by private consulting firms and government agencies, as well as published articles. Both pre-project environmental impact studies and post-project monitoring of actual effects can be used to understand the impacts of various types of projects on wetlands. Well-known examples of environmental impact studies and subsequent monitoring include the exploration of the National Petroleum Reserve in 1979, the Waterflood project (19801985) at Prudhoe Bay, the Endicott Causeway, the trans-Alaska pipeline (Alexander and Van Cleve 1983), the proposed gas pipeline and the proposed Susitna hydroelectric project. One of the earliest Alaska environmental impact studies was conducted at Point Thompson in northwest Alaska (Project Chariot) in the 1960s (Wilimovsky and Wolfe 1966), where theenvironment was described because of a proposal to use nuclear explosives to build a deep-water port.

Measurements of impacts from these activities involve the amount of soil and vegetation removed or buried under gravel fill, disturbance to wildlife, and changes in the hydrology (ponding or drainage), sedimentation and ground thermal regime, particularly where permafrost is present. Thermokarst is a well-known impact of surface disturbance in permafrost wetlands in Alaska (Lawson 1983). Flooding of an area or removal of vegetation and associated organic soils alter the ground thermal regime, resulting in thawing of ice-rich sediments and subsidence of the ground surface, followed by erosion on slopes. CRREL has produced detailed studies of this phenomenon, both from an engineering and an ecological standpoint (Lawson 1986). Other impacts include 
changes in water quality due to contaminants including oil spills and dust.

At least two review papers summarize these effects in arctic Alaska: "Disturbance and Recovery of Alaskan Tundra Terrain: A Summary of Recent CRREL Research" (Walker et al. 1987a) and the Environmental Protection Agency's summary of the impacts of oil development in northern Alaska, particularly with reference to the effects of gravel placement on wetlands and waterbirds (Meehan 1988). This report also contains an annotated bibliography of literature on waterbirds and surface impacts on the North Slope of Alaska. A large-scale Department of Energy research program in progress on the North Slope (R4D at Toolik Lake) seeks to understand how environmental changes (impacts) such as nutrient inputs and temperature change affect basic tundra wetland processes.

\section{Oilfields}

In Alaska oil and gas exploration and development have taken place in wetlands on the North Slope and in the Kenai peninsula (southcentral region). The associated activities and impacts range from off-road vehicle seismic studies and construction of test well pads to actual oilfield development with pipelines, gravel roads, drill sites, well pads, powerlines and gravel mines (Meehan 1988). Long-term impacts of exploratory drilling (during the summer) at several sites on the North Slope in the 1940s have been documented (Lawson et al. 1978). The impacts of more recent seismic exploratory programs (during the winter) in the Seward Peninsula and in Arctic National Wildlife Refuge, respectively, have also been well documented by Racine and Anderson (1979) and Felix and Raynolds (1989), showing localized disturbances from winter seismic exploration.

CRREL has also documented many of the engineering and ecological changes associated with the construction of the trans-Alaska pipeline (Brown and Berg 1980). Alluvial deposits found in broad floodplains offer one of the prime sources of gravel for road and pad construction in northern areas. Such gravel mining can exert a significant impact on riverine wetlands in terms of seasonal flooding, streamflow and vegetation cover. Woodward-Clyde Consultants (1980) prepared a report describing the impacts of gravel removal on rivers based on measurements at 25 extraction sites. Other impacts associated with gravel roads include late-melting snowbanks from plowing, gravel extraction mines and overburden piles. Indirect and cumulative impacts of oilfield development are discussed below.

\section{Agriculture and forestry}

At least two large Alaskan agricultural projects (Pt. MacKenzie in upper Cook Inlet and Delta Junction in the interior) have resulted in significant wetland impacts. The largest of these, in the Delta Junction area, involved the clearing of large areas where black spruce permafrost wetlands occupied over $50 \%$ of the area. The other project, at Pt. MacKenzie, resulted in impacts to fewer wetland acres. Perhaps $25 \%$ of the area cleared there was originally wetland. Historically other agricultural projects such as reindeer herding in the Seward Peninsula have had significant effects on wetland vegetation (Palmer and Rouse 1945). Some logging occurs in floodplains in interior Alaska. In southeastern Alaska, coastal log transfer sites are constructed and affect some coastal wetlands.

\section{Mining}

In Alaska the most extensive mining currently involves coal extraction, which generally takes place in non-wetland conditions. However, the Beluga coal fields west of Anchorage underlie several thousand acres of wetlands and may be developed in the future. Another coal field in the Chugach National Forest (Bering River) may require construction of a road crossing parts of the Copper River Delta wetlands.

Current and past gold mining (placer mining) often involves riverine wetlands, on which the impact can be considerable. The Seward Peninsula in northwest Alaska has produced nearly $30 \%$ of the placer gold mined in Alaska. Hydraulic mining techniques are still used, and sedimentation probably occurs downstream from such mining operations. However, there is little information on impacts of these operations. T. Jorgenson of Alaska Biological Research is investigating methods of revegetating floodplain placer mining in interior Alaska.

Other minerals being mined in the Seward Peninsula include tin, zinc and copper. The recent development of the Red Dog Mine north of Kotzebue has undoubtedly affected some wetlands (where roads were constructed), although the mine itself is located in the uplands. There is generally little information on the impact of these mining activities on northwest Alaskan wetlands.

Although peat mining in bogs is described as extensive in other countries where it is used for 
energy, no peat mining occurs in Alaska except on a small scale.

\section{Development and recreation}

Urban expansion in Anchorage and Fairbanks, as well as other cities and towns such as Juneau, Kenai, Soldotna and Homer, have had significant impacts on wetlands. In addition, recreational development along rivers and lakeshores in the Kenai Peninsula have affected wetlands and associated wildlife (Bangs et al. 1982, Rosenberg 1986).

\section{Hydroelectric developments}

Several hydroelectric projects have been planned or built in the southcentral and southeast regions, where peak demands are greatest. The proposed Susitna River project would have had a significant impact on wetlands and involved a large number of studies, including the mapping of the entire basin by the SCS. Bradley Lake in the Kenai Peninsula was found to affect a downstream estuarine salt marsh (Jones and Jones 1975). Other northern energy projects for which impact studies have been conducted include the James Bay hydro project in Quebec, Canada (Berkes 1988). In the James Bay case almost $4000 \mathrm{mi}^{2}$ were flooded, with several unpredicted impacts, such as mercury release, caribou drownings and wetland alterations.

\section{Current issues in wetland impacts}

The possible cumulative impact of oil and gas development in the Arctic region on wildlife and wetlands is an important issue and lacks a means to evaluate it. It is estimated as inconsequential by some and disastrous by others. Only a small fraction of the total wetland area on the North Slope has actually been filled by oilfield development (in 1987, gravel covered 8650 acres of North Slope oilfields).

However, indirect and cumulative impacts extend out from these gravel pads and roads in North Slope wetlands; these include impeded drainage (impoundments), permafrost thaw and dust (Walker et al. 1987b). Dust deposition along heavily traveled roads at Prudhoe Bay may extend up to $75 \mathrm{~m}$ from the road and eliminate certain moss and lichen species, increase thaw depths and lead to earlier snowmelt (Meehan 1988). Many gravel roads at Prudhoe Bay also block drainage and create permanent or seasonal impoundments (in 1983 there were 3400 acres of impoundments). While some aquatic vegetation may be eliminated because of increased water depth, others may show increased production. Most waterbird species avoid impoundments during the breeding season. The oil companies maintain that impacts and management of projects can only be evaluated through the monitoring of wildlife populations in affected wetlands after the project is completed (Senner 1989). Their monitoring suggests that populations are not declining and that the direct cumulative habitat loss through gravel fill does not affect populations because there is abundant unoccupied habitat (vacant rooms) in the North Slope oilfields. While abundant monitoring studies exist for the oilfield construction projects, the federal agencies have recently proposed that the focus of such impact studies be habitat alteration rather than population monitoring (Post 1990). Population monitoring is prohibitively expensive, and wildlife population sizes change from year to year. Habitat-based wetland management is both efficient and cost effective.

\section{Knowledge gaps}

As is clear from this discussion, the values and functions of North Slope and other permafrostinduced wetlands are being debated, and the scope and degree of development and consequent loss of wetlands that can be sustained in various regions without affecting wildlife populations are largely unknown.

Assessment of cumulative impacts to wetlands, although required by NEPA (the National Environmental Policy Act), has not been addressed, but some attention has been given to the problem on the North Slope. Meehan et al. (1986) provided a framework and approach to the problem in terms of cumulative impacts from oil and gas development on the North Slope. As new oilfields are developed, it is important to determine the cumulative impact of each new proposed project. However, no accepted and applied methodology for cumulative impact assessment exists. Meehan et al. (1986) stated that shorebirds are certainly affected by the cumulative impact of expanding oilfield facilities and that the effects are quantifiable.

\section{MITIGATION OF IMPACTS AND RESTORATION OF WETLANDS}

Individual or collective actions taken to offset adverse project impacts are termed mitigation. The Council on Environmental Quality (CEQ) lists five types of mitigation: 
"a) avoiding the impact altogether by not taking a certain action or parts of an action; b) minimizing impact by limiting the degree of magnitude of the action and its implementation; c) rectifying the impact by repairing, rehabilitation, or restoring the affected environment; d) reducing or eliminating the impact over time by preservation or maintenance operations during the life of the action; and e) compensating for the impact by replacing or providing substitute resources or environments."

Review papers on mitigation of impacts in wetlands include a 1986 National Wetland Symposium entitled Mitigation of Impacts and Losses (Kusler et al. 1986). In April 1990 a National Wetland Symposium on wetland restoration was held, and the proceedings are available (Kusler and Kentula 1990). Other sources of information include Rehabilitation and Creation of Selected Coastal Habitats: Proceedings of a Workshop (Lewis and Bunce 1980). The EPA has recently published a report entitled Wetland Creation and Restoration: The Status of the Science (Kusler and Kentula 1989).

The mitigation of impacts in arctic and subarctic regions was recently addressed by a symposium in Iceland (Salzberg 1987) entitled Restoration and Revegetation in Northern Circumpolar Lands. CRREL personnel contributed to this symposium and earlier reviewed revegetation research in Alaska (Johnson and Van Cleve 1976, Walker et al. 1989). Restoration guidelines for northern areas have been described by the Canadian Indian and Northern Affairs (Hardy BBT Ltd. 1988). Meehan (1988) recommended ways of mitigating a number of North Slope oilfield impacts, including gravel pads and mines, impoundments, dust and snowbanks.

Impacts in North Slope wetlands can be minimized by using mapping and remote sensing techniques to route traffic and road construction so as to avoid sensitive wetland areas, such as drained thaw lakes (Walker et al. 1987a). Proper citing of facilities can reduce erosion, water contamination, impoundments and thermokarst and avoid high-value wildlife habitat. For example, gravel for road and pad construction can be excavated from deep pits in upland areas rather than shallow scraping of gravel from floodplain wetlands. Improvements in directional drilling have allowed the use of more wells per gravel pad and smaller pads. Where gravel has been mined in floodplains, the impact can be mitigated by flood- ing and the creation of adjacent shallow water zones to provide overwintering areas for fish. Then site contouring can be used to establish the appropriate hydrologic characteristics, organic matter added to promote development of a detrital food chain, and certain aquatic plants introduced.

The present review concentrates on rectifying impacts by repairing, rehabilitating or restoring the affected environment. Restoration of disturbed oilfield wetlands in the Arctic is difficult and may involve manipulating hydrology, reconstructing soils and developing new plant materials and planting techniques.

A broad range of wetland restoration projects have been undertaken in Alaska, but many have never been documented in a written report. Among the wetland sites where restoration efforts have been undertaken are oilspill areas on the North Slope (McKendrick and Mitchell 1978), pipeline haul road and corridor (Johnson 1981), riparian gravel sites (Densmore et al. 1987) and oilfield gravel pads, roads and mine sites (Jorgenson 1989).

\section{Current issues in mitigation}

The rehabilitation of abandoned oilfields will eventually be an important issue in Alaska, and it is important to develop plans and schedules now. Senner (1989), in his contract report for the oil companies, argued that on the North Slope the construction of gravel pads and roads is a form of mitigation rather than an impact (i.e. prevention of permafrost degradation) and is sufficient to fulfill the mitigation requirements of the 404 permit. $\mathrm{He}$ also argued that the revegetation of these gravel pads is only aesthetic or cosmetic and would produce little or no restoration of lost wild life habitat. The cost of wetland restoration in the Arctic is high, and it is important that the effort accomplish the desired goals, particularly in relation to wildlife habitat.

Jorgenson (1989) provided an excellent overview of rehabilitation research between 1984 and 1989 in the Kuparuk oilfield on the Arctic coastal plain. Techniques for restoring wetlands and other sites there are aimed primarily at rehabilitating fish and wildlife habitat, with other objectives including preventing hydraulic erosion, restoring productivity and species diversity to conditions similar to the surrounding vegetation, revegetating with native cultivars to compensate for the loss of original habitat, reducing visual impacts and preventing thermal erosion. A major need is to develop a set of realistic standards for evaluating such restoration efforts in these oilfields. 


\section{Restoration}

Restoration usually refers to the long-term process of returning a site to conditions similar to the original one. Rehabilitation refers to the overall process of site repair, including soil reconstruction, hydrologic modification, erosion control and revegetation. In addition, restoration may have an active-assisted or passive-unassisted revegetation component. Assisted revegetation of wetlands ranges from promoting the natural colonization of disturbed sites (through fertilization, scarification etc.) to full-scale site preparation, contouring, fertilization and seeding. It is important that all wetland restoration projects first evaluate the benefits of natural revegetation vs. assisted revegetation techniques.

\section{Unassisted restoration}

Northern wetlands vary in their ability to resist impacts or disturbances and in their ability to recover once disturbed (that is, they vary in resilience). Therefore, some types of wetlands, when disturbed in specific ways, may recover without assistance over short or long periods of time. In evaluating the mitigation strategy for various projects, this type of information may be useful. Expensive active restoration projects may be unnecessary if the ecosystem can repair itself in a reasonable length of time. In northern Alaska a number of studies have been undertaken to determine the rate and direction of revegetation and recovery (natural attenuation) following natural or man-caused disturbances (Walker et al. 1987a). Natural disturbances, including flooding, lake drainage, wildfire and bank erosion, can provide models for understanding the recovery of manproduced surface disturbances such as off-road vehicle trails, bulldozed strips and gravel pads. These studies have been accomplished by monitoring disturbed sites and by revisiting disturbances up to 25 years old (Lawson et al. 1978, Everett et al. 1985, Racine et al. 1987).

Results show that wetlands recovery in permafrost depends on stabilization of the thawing substrate and the amount of thermal erosion. Moist tundra (tussock-shrub tundra) is initially more resistant to mechanical damage than wet communities, but once altered it is slower to recover (Komarkova 1983). The presence of organic materials in disturbed site soils is important to early recovery. Both bryophytes and grasses, as well as a limited number of forbs, generally colonize disturbed arctic wetland sites that have organic matter. The thick organic horizon of arctic wetland soils frequently contains stored seeds and propagules (Roach 1983). If this horizon is not removed by the disturbance, these seeds germinate to establish new vegetation. Organic material also increases the moisture-trapping capacity and nutrient capital needed for reestablishing vegetation. However, organic material in the soil may also dry out rapidly and in some situations is a poor substrate for seedling establishment. Phosphorus is frequently limiting, and fertilization increases revegetation on many sites (McKendrick 1987). In wet organic soils, available nitrogen is also low.

An understanding of successional pathways of natural plant colonization is needed to help direct wetland rehabilitation programs in places like the North Slope oilfields (McKendrick 1987, Jorgenson 1989). These studies of unassisted recovery have also led to the identification of native cultivars, which have been subsequently tested by the Alaska plant materials center.

\section{Gravel fill restoration}

Unassisted revegetation in arctic wetlands is clearly slow, particularly on well-drained gravel pads and roads or on mineral soil sites without organic matter. Although there are a number of arctic species, including nitrogen-fixing legumes, that colonize river gravel bars, sand dunes and coastal sediments in Alaska, these do not appear to invade constructed gravel roads and pads except when near rivers.

The most difficult sites to restore are thick gravel pads (over $1 \mathrm{~m}$ thick) or roads that have been constructed in wetlands (Johnson 1981). Where pads are thinner than $1 \mathrm{~m}$, the capillary rise of groundwater provides nutrients and reduces moisture stress in plants. On thick gravel pads the low soil moisture of the well-drained gravels and a buildup of saline soil conditions is not conducive to seed germination and seedling establishment. Jorgenson (1989) has investigated the use of constructed gravel berms to help capture drifting snow, which would increase the soil moisture and reduce the salinity on gravel pads in the Kuparuk oilfield.

\section{Restoration of shallow marshes}

Plant material development for the North Slope oilfields has recently focused on the use of the aquatic grass Arctophila fulva for plantings in shallow water, usually near mine sites, to enhance waterfowl and shorebird habitat. An intensive five-year study of Arctophila fulva begun in 1985 
(McKendrick 1988) showed that it provides forage for geese and swans, contributes to organic detritus for invertebrates and transplants easily.

\section{Knowledge gaps}

A broad range of wetland restoration projects have been conducted in Alaska over the past 20 years. Many have been undertaken but never presented in a written report. A database cataloging the details and success of these attempts should be developed. Techniques for restoring wetlands where gravel fill has been used need to be refined. Success criteria need to be developed to determine the way in which wildlife use restored areas and how wildlife use affects the rate of revegetation. In addition a technique is needed to identify which oilfield gravel pads and roads should be removed or restored once an area is abandoned. This should be based on the relative value of the wetlands where the fill has been placed.

\section{CONCLUSIONS}

A large body of literature on circumpolar arctic and subarctic wetlands is available, much of it from Canadian and European-Russian sources. Because plant and animal species and soils throughout this large area are similar and many of the same processes operate to maintain and produce wetlands, it is possible to apply literature on wetlands from one region of the north to other areas. Throughout the circumpolar north, wetland soils tend to store large amounts of organic carbon, and in the more northern regions, permafrost acts to promote wetland development. Important aspects of northern wetlands include hydrologic processes (water tables, snowmelt etc.), riverine flooding and permafrost aggradation-degradation (thermokarst), vegetation succession (including paludification), climate change and energy inputs, along with disturbances such as wildfire.

The application of a large body of technical literature dealing with wetland processes and organisms in circumpolar and circumboreal regions to wetland management and regulation is problematic. Wetland regulators and managers are not concerned with processes controlling wetland development; they are charged with the protection of wetlands, requiring first the jurisdictional identification of wetlands, their functions and values in relation to human and legal concerns (i.e. flood protection, water quantity and quality, wildlife habitat and threatened and endangered spe- cies). However, managers are concerned with the impacts of human actions on wetlands and techniques for repairing or restoring damaged wetlands to their original condition. In permafrost regions of the north, natural processes involving wildfire, vegetation succession, thermokarst and climate change may convert wetlands to non-wetlands and vice versa.

\section{LITERATURE CITED}

Acevedo, W., D. Walker, L. Gaydos and J. Wray (1982) Vegetation and land cover, Arctic National Wildlife Refuge, Coastal Plain. Alaska Miscellaneous Inventory Series Map I-1443, U.S. Geological Survey, Reston, Va.

Adamus, P. (1987) Juneau wetlands: Functions and values. Adamus Resource Assessment Inc. Unpublished report to the City of Juneau.

Adamus, P.R., E.J. Clairain, R.D. Smith and R.E. Young (1987) Wetland evaluation technique (WET). Vol. II. U.S. Army Engineer Waterways Experiment Station, Vicksburg, MS.

Alexander, V. and K. Van Cleve (1983) The Alaska pipeline: A success story. Annual Review of Ecology and Systematics, 14: 443-463.

Bangs, E., T. Spraker, T. Bailey and V. Berns (1982) Effects of increased human populations on wildlife resources on the Kenai Peninsula, Alaska. Transactions of the 47th North American Wildife and Natural Resources Conference, p. 605-616.

Batten, A.R. (1980) A proposed classification framework for Alaskan wetland and aquatic vegetation. Final report to U.S. Forest Service by Institute of Arctic Biology, University of Alaska.

Batten, A.R. (1986) A synopsis of Alaskan wetland vegetation. In Alaska: Regional Wetland Functions (A. Van der Valk and J. Hall, Ed.). Anchorage, Alaska: The Environmental Institute, University of Massachusetts.

Batten, A.R. and D.F. Murray (1982) A literature survey on the wetland vegetation of Alaska. U.S. Army Corps of Engineers Waterways Experiment Station. Technical Report Y-82-2.

Batten, A.R., S. Murphy and D.F. Murray (1978) Definition of Alaskan coastal wetlands by floristic criteria. Final Report, EPA 80496501, Corvallis Research Laboratory, Oregon.

Bergman, R.D., R.L. Howard, K.F. Abraham and M.W. Weller (1977) Water birds and their wetland resources in relation to oil development at Storkersen Point, Alaska. U.S. Fish Wildlife Service, Washington, D.C., Resource Publication 129. 
Berkes, F. (1988) Intrinsic difficulty of predicting impacts: Lessons from the James Bay hydro project. Environmental Impact Assessment Review, 8(3): 201220.

Bliss, L.C., O.W. Heal and J.J. Moore (1981) Tundra Ecosystems: A Comparative Analysis. International Biological Programme 25. Cambridge:Cambridge University Press.

Botch, M.S. (1974) Bogs in the tundra zone of Siberia. Bog Types of the U.S.S.R. and Principles of their Classification. Ottawa, Ontario, Canada: National Research Council of Canada, 1974. Technical Translation no. 1925, p. 146-154.

Brown,J. and R.L. Berg (Ed.) 1980. Environmental engineering and ecological baseline investigations along the Yukon River-Prudhoe Bay Haul Road. USA Cold Regions Research and Engineering Laboratory, CRREL Report 80-19.

Brown, J., P.C. Miller, L.L. Tieszen and F.L. Bunnell (Ed.) (1980) An Arctic Ecosystem: The Coastal Tundra at Barrow, Alaska. US/IBP Synthesis Series 12. Stroudsburg, Pennsylvania: Dowden, Hutchinson and Ross, Inc.

Chapin, F.S. III., P.C. Miller, W.D. Billings and P.I. Coyne (1980) Carbon and nutrient budgets and their control in coastal tundra. In An Arctic Ecosystem: The Coastal Tundra at Barrow, Alaska (J. Brown, P.C. Miller, L.L. Tieszen and F.L. Bunnell, Ed.). Stroudsburg, Pennsylvania: Dowden, Hutchinson and Ross, Inc., p. 458-482.

Cowardin, L.M., V.C. Carter, F.C. Golet and E.T. LaRoe (1979) Classification of wetlands and deepwater habitats of the United States. U.S. Fish and Wildlife Service, Office of Biological Services. DeMeo, T.E. and W.D. Loggy (1989) Development of wetlands mapping procedures for forest planning in southeast Alaska. Watershed ' 89 (E.B. Alexander, Ed.). U.S. Forest Service, Juneau, Alaska, Alaska Region R10-MB-77, p. 57-72.

Densmore, R.V., B.J. Neiland, J.C. Zasada and M.A. Masters (1987) Planting willow for moose habitat restoration on the north slope of Alaska, USA. Arctic and Alpine Research, 19: 537-543.

Derksen, D.V., T.C. Rothe and W.D. Eldridge (1981) Use of wetland habitats by birds in the National Petroleum Reserve-Alaska. U.S. Fish and Wildlife Service, Research Publication 141.

Diers, R. and J.L. Anderson (1984) Part I. Development of soil mottling. Soil Survey Horizons, Winter: 9-12.

Drury, W.H. (1956) Bog flats and physiographic processes in the upper Kuskokwim River region, Alaska. Contributions of the Gray Herbarium, 178, 130.
Ellanna, L.J. and G.K. Sherrod (1986) Adamus wetland functional assessment methodology: Subsistence. In Alaska: Regional Wetland Functions (A. Van der Valk and J. Hall, Ed.). Anchorage, Alaska: The Environmental Institute, University of Massachusetts.

Everett, K.R., B.M. Murray, D.F. Murray, A.W. Johnson, A.E. Linkins and P.J. Webber (1985) Reconnaissance observations of long-term natural vegetation recovery in the Cape Thompson region, Alaska, and additions to the checklist of flora. USA Cold Regions Research and Engineering Laboratory, CRREL Report 85-11.

Federal Interagency Committee for Wetland Delineation (1989) Federal manual for identifying and delineating jurisdictional wetlands. U.S. Army Corps of Engineers, U.S. Environmental Protection Agency, U.S. Fish and Wildlife Service and U.S.D.A. Soil Conservation Service, Washington Cooperative Technical Publication.

Felix, N.A. and M.K. Raynolds (1989) The effects of winter seismic trails on tundra vegetation in northeastern Alaska, U.S.A. Arctic and Alpine Research, 21: 188-202.

Ferrians, O.J. (1965) Permafrost map of Alaska. Miscellaneous Geologic Investigations Map I-445, U.S. Geological Survey, Washington, D.C.

Ford, J. and B. L. Bedford (1987) The hydrology of Alaskan wetlands, U.S.A.: A Review. Arctic and Alpine Research, 19: 209-229.

Glaser, P.H. (1987) The ecology of patterned boreal peatlands of northern Minnesota: A community profile. U.S. Fish and Wildlife Service, Biological Report 85 (7.14).

Glass, R.L. (1986) Hydrolgic conditions in the Klatt Bog area, Anchorage, Alaska. U.S. Geological Survey, Water-Resources Investigation Report 85-4330.

Hall, J. V. (1988) Alaska coastal wetlands survey. National Wetlands Inventory, Alaska. U.S. Fish and Wildlife Service. Unpublished report.

Handel, C.M., M.R. Petersen, R.E. Gill and C.J. Lensink (1981) An annotated bibliography of literature on Alaska water birds. U.S. Fish and Wildlife Service, FWS/OBS-81/12.

Hardy BBT Ltd. (1987) Reclamation guidelines of Northern Canada. Canada Land Resources and Northern Affairs, Ottawa.

Hettinger, L.R. and A.J. Janz (1974) Vegetation and soils of northeastern Alaska. Arctic Gas Biological Report Series, Vol 21. Northern Engineering Services Co. Ltd.

Hobbie, J.E. (Ed.) (1980) Limnology of Tundra Ponds, Barrow, Alaska. US/IBP Synthesis Series 13. 
Stroudsburg, Pennsylvania: Dowden, Hutchinson and Ross.

Hobbie, J.E. (1984) The ecology of tundra ponds of the arctic coastal plain: A community profile.U.S. Fish and Wildlife Service, FWS/OBS-83/25.

Hogan, M. and G.F. Tande (1983) Vegetation types and bird use of Anchorage wetlands. U.S. Fish and Wildlife Service, Anchorage, Alaska, Region 7 Special Studies.

Huffman, R.T. and G.E. Tucker (1984) Preliminary guide to the onsite identification and delineation of the wetlands of Alaska. U.S. Army Corps of Engineers Waterways Experiment Station, Technical Report Y-78-9.

Johnson, L.A. (1981) Revegetation and selected terrain disturbances along the trans-Alaska pipeline, 1975-1978. USA Cold Regions Research and Engineering Laboratory, CRREL Report 81-12.

Johnson, L.A. and K. Van Cleve (1976) Revegetation in arctic and subarctic North America. A literature review. USA Cold Regions Research and Engineering Laboratory, CRREL Report 76-15.

Jones and Jones (1975) Bradley Lake environmental assessment. Alaska District, U.S. Army Corps of Engineers, Anchorage, Alaska.

Jorgenson, M.T. (1989) An overview of rehabilitation research in the Kuparuk oilfield. Final Report prepared for ARCO Alaska, Inc. and Kuparuk River Unit by Alaska Biological Research Inc., Fairbanks, Alaska.

Jorgenson, M.T. and E.E. Berg (1987) Wetlands of Homer. Alaska Biological Research, Inc, Fairbanks, Alaska.

Kane, D. (Ed.) (1990) Symposium: Cold Region Hydrology, Fairbanks, Ak (1986). American Water Resources Association.

Kane, D.L., S.R. Bredthauer and J. Stein (1981) Subarctic snowmelt runoff generation. In Proceedings of the Special Conference on the Northern Community: A Search for a Quality Environment, ASCE, Seattle, Washington, p. 591-601.

Kessel, B. (1979) Avian habitat classification for Alaska. Murrelet, 60: 86-94.

Komarkova, V. (1983) Recovery of plant communities and summer thaw at the 1949 Fish Creek Test Well 1, Arctic Alaska. In Permafrost: Fourth International Conference, Proceedings, 17-22 July 1983, Fairbanks, Alaska. National Academy Press Washington, D.C., p. 645-650.

Kusler, J.A. and M.E. Kentula (1990) Wetland Creation and Restoration: The Status of the Science. Washington, D.C.: Island Press.

Kusler, J.A., M.L. Quammen and G. Brooks (Ed.) (1986) Proceedings of the National Wetland Sympo- sium: Mitigation of Impacts and Losses. Association of State Wetland Managers, New York.

Lawson, D.E. (1983) Erosion of perennially frozen streambanks. USA Cold Regions Research and Engineering Laboratory, CRREL Report 83-29.

Lawson, D.E. (1986) Response of permafrost terrain to disturbance: A synthesis of observations from northern Alaska, USA. Arctic and Alpine Research, 18: 1-17.

Lawson, D.E., J. Brown, K.R. Everett, A.W. Johnson, V. Komarkova, B.M. Murray, D.F. Murray and P.J. Webber (1978) Tundra disturbances and recovery following the 1949 exploratory drilling, Fish Creek, northern Alaska. USA Cold Regions Research and Engineering Laboratory, CRREL Report 78-28.

Lee, L.C.r R.O. Teskey and T.M. Hinckley (1982) Impact of water level changes on woody riparian and wetland communities. Vol. IX: Alaska. U.S. Fish and Wildlife Service, FWS/OB5-82/22.

Lensink, C.J. and D.V. Derksen (1986) Evaluation of Alaskan wetlands for waterfowl. In Alaska: Regional Wetland Functions (A. Van der Valk and J. Hall,Ed.). Anchorage, Alaska: The Environmental Institute, University of Massachusetts, p. 45-84.

Lewis, J. C. and E.W. Bunce (Ed.) (1980) Rehabilitation and creation of selected coastal habitats: Proceedings of a workshop. U.S. Fish and Wildlife Service, FWS/OB5-80/27.

Lynch, J.J. (1940) Origin and natural maintenance of some arctic waterfowl habitats. U.S. Fish and Wildlife Service. Unpublished report.

Marcus, M.L. (1983) Wetland use and regulation: Alaska case study. Final report, Office of Technology Assessment, Congressional session 98-1.

Markon, C.J. (1980) Terrestrial and aquatic habitat mapping along the Alaska natural gas pipeline system. U.S. Fish and Wildlife Service, Anchorage, Alaska, Special Studies.

McKendrick; J.D. (1987) Plant succession on disturbed sites, North Slope, Alaska, USA. Arctic and Alpine Research, 19 (4): 554-565.

McKendrick, J.D. (1988) Arctophila revegetation feasibility study, 1987. Annual report to Standard Alaska Production Co.

McKendrick, J.D. and W.W. Mitchell (1978) Fertilizing and seeding oil-damaged arctic tundra to effect vegetation recovery, Prudhoe Bay, Alaska. Arctic, 31: 296-304.

Meehan, R. (1988) Oil development in northern Alaska: A guide to the effects of gravel placement on wetlands and waterbirds. Environmental Protection Agency, Environmental Research Laboratory, Corvallis, Oregon. 
Meehan, R. and T.W. Jennings (1988) Characterization and value ranking of waterbird habitat on the Colville River Delta, Alaska. Final report prepared for EPA, U.S. Fish and Wildlife Service, Anchorage, Alaska.

Meehan, R., P.J. Webber and D. Walker (1986) Tundra development review: Toward a cumulative impact assessment method. Report to U.S. Environmental Protection Agency, under U.S. Department of Energy DE-A106-84RL.

Mitsch, W. J. and J. G. Gosselink (1986) Wetlands. Van Nostrand Reinhold: New York.

Murphy, S., B. Kessel and L. Vining (1984) Waterfowl populations and limnologic characteristics of taiga ponds. 48: 1156-1163.

National Technical Committee for Hydric Soils (1987) Hydric soils of the United States. U.S. Department of Agriculture, Soil Conservation Service, Washington, D.C.

National Wetlands Working Group (1988) Wetlands of Canada.Sustainable Development Branch, Environment Canada, Ottawa, Ontario, and Polyscience Publications Inc., Montreal, Quebec, Ecological Land Classification Series No. 24.

Needham, R.N. and T.M. Skordal (1987) Summary of wetland mapping, Juneau, Alaska. Alaska District, Corps of Engineers, Anchorage, Alaska.

Oakley, K.J., Glaspel, G.E. Tande and T. Jennings (1987) Wetlands and their use by fish in the lower Salmon Creek drainage, Seward, Alaska. Alaska Department of Fish and Game, Habitat Division, Region II, Anchorage, Alaska.

Palmer, L.H. and C.H. Rouse (1945) Study of the Alaska tundra with reference to its reactions to reindeer and other grazing. U.S. Department of Interior, Fish and Wildlife Service, Research Report 10.

Pitelka, F.A., R.T. Holmes and S.F. Maclean, Jr. (1974) Ecology and evolution of social organization in arctic sandpipers. American Zoologist, 14: 185-204.

Post, R. (1990) Arctic tundra wetlands: Values and management. Alaska Fish and Game, 22: 14-17.

Racine, C.H. and J. A. Anderson (1979). Flora and vegetation of the Chuckchi-Imuruk area. In Biological survey of the Bering Land Bridge National Monument (H.R. Melchior, Ed.). Report to the U. S. Department of Interior, National Park Service, Contract No. CX 9000-3-0316, p. 38-113

Racine, C.H. and E. Hamilton (1980) Mapping and classification of freshwater wetlands in the Anchorage Alaska area. Final report, Oceanographic Institute of Washington, Seattle, Washington.
Racine, C.H., L.A. Johnson and L.A. Viereck (1987) Patterns of vegetation recovery after tundra fires in northwestern Alaska, USA. Arctic and Alpine Research, 19: 461-469.

Reed, P.B. (1988) National list of plant species that occur in wetlands: Alaska (Region A). U.S. Fish and Wildlife Service, Biological report 88(26.11). Reiger, S., D.B. Schoephorster and C.E. Furbush (1979) Exploratory soil survey of Alaska. USDA Soil Conservation Service.

Ritchie, R., J. Curatolo and A. Batten (1981) Knik Arm wetland study. Special Studies, U.S. Fish and WildlifeServices, Anchorage, Alaska, unpublished report.

Roach, D.A. (1983) Buried seed and standing vegetation in two adjacent tundra habitats, northern Alaska. Oecologia, 60: 359-364.

Robertson, S.B. (1987) Hydrology of arctic wetlands. In Proceedings of the National Wetland Symposium: Wetland Hydrology (J.A. Kusler and G. Brooks, Ed.). Association of State Wetland Managers, Inc.

Rosenberg, D.H. (1986) Wetland types and bird use of Kenai lowlands. Special Studies, U.S. Fish and Wildlife Service, Anchorage, Alaska.

Rothe, T.C., S.H. Lanigan, P.A. Martin and G.F. Tande (1983) Natural resource inventory of Elmendorf Air Force Base, Alaska. SpecialStudies, U.S. Fish and Wildlife Service, Anchorage, Alaska. Salzburg, K. (Ed.) (1987) Restoration and vegetation succession in circumpolar lands, Proceedings of conference, Reykjavik, Iceland. Arctic and Alpine Research, 19.

Senner, R.G.B. (1989) Effects of petroleum operations in Alaskan wetlands. Robert Senner and Co. for ARCO Alaska and BP Exploration, Anchorage. Soil Conservation Service (1985) Hydric Soils of the United States. U.S. Department of Agriculture, Washington, D.C.

Swanson, D. (1985) Range survey of the Seward Peninsula reindeer ranges, Alaska. USDA Soil Conservation Service.

Talbot, S. and C.J. Markon (1988) Vegetation mapping of Nowitna National Wildlife Refuge, Alaska using Landsat MSS digital data. Photogrammatic Engineering and Remote Sensing, 52: 791-799.

Tande, G.F. and T.W. Jennings (1986) Classification and mapping of tundra near Hazen Bay Yukon Delta National Wildlife Refuge, Alaska. U.S. Fish and Wildlife Service.

Thilenius, J.F. (1990) Woody plant succession on earthquake-uplifted coastal wetlands of the Copper River Delta, Alaska. Forest Ecology and Manage- 
ment, 33/31: 439-462.

Van der Valk, A and J. Hall (Ed.) (1986) Alaska: Regional Wetland Functions. Anchorage, Alaska: The Environmental Institute, University of Massachusetts.

Van Cleve, K. and L.A. Viereck (1983) A comparison of successional sequences following fire on permafrost-dominated and permafrost-free sites in interior Alaska. In Proceedings, Fourth International Conference on Permafrost. Washington D.C.: National Academy Press.

Van Cleve, K., F.S. Chapin III, P.W. Flanagan, L.A. Viereck and C.T. Dyrness (Ed.) (1986) Forest Ecosystems in the Alaskan Taiga. A Synthesis of Structure and Function. New York: Springer Verlag.

Viereck, L.A., C.T. Dyrness and A.R. Batten (1981) Revision of preliminary classification system for vegetation of Alaska. U.S. Department of Agriculture, Forest Service, General Technical Report PNW-106.

Viereck, L.A., C.T. Dyrness and A.R. Batten (1986) The 1986 revision of the Alaska vegetation classification. USDA Forest Service, Institute of Northern Forestry, Fairbanks, Alaska. Unpublished report.

Walker, D.A. and W. Acevedo (1987) Vegetation and a landsat-derived land cover map of the Beechey Point quadrangle, Arctic Coastal Plain, Alaska. USA Cold Regions Research and Engineering Laboratory, CRREL Report 87-5

Walker, D.A. and P.J. Webber (1979) Report of Yukon River to Prudhoe Bay vegetation mapping program. Institute of Arctic and Alpine Research, University of Colorado, Int. Rep. 607.

Walker, D.A., W. Acevedo, K.R. Everett, L.
Gaydos,J. Brown and P.J. Webber(1982) Landsatassisted environmental mapping in the Arctic National Wildlife Refuge, Alaska. USA Cold Regions Research and Engineering Laboratory, CRREL Report 82-37.

Walker, D.A., D. Cate, J. Brown and C. Racine (1987a) Disturbance and recovery of arctic Alaskan tundra terrain: A review of recent investigations. USA Cold Regions Research and Engineering Laboratory, CRREL Report 87-11.

Walker, D.A., P.J. Webber, E.F. Binnian, K.R. Everett, N.D. Lederer, E.A. Nordstrand and M.D. Walker (1987b) Cumulative impacts of oil fields on northern Alaskan landscapes. Science, 238: 757761.

Walker, M.D., D.A.Walker and K.R. Everett (1989) Wetland soils and vegetation, Arctic foothills, Alaska. U.S. Fish and Wildlife Service, Biological Report 89(7).

Wilimovsky, N.J. and J.N. Wolfe (Ed.) (1966) Environment of the Cape Thompson region, Alaska. U.S. Atomic Energy Commission, Division of Technical Information, PNE-481, Oak Ridge, Tennessee.

Woo, M.K. and P. Steer (1986) Runoff regime of slopes in continuous permafrost areas. Canadian Water Resources Journal, 11: 58-68.

Woodward-Clyde Consultants (1980) Gravel removal studies in arctic and subarctic floodplains in Alaska. Fish and Wildlife Service, Biol. Serv. Program FWS/OBS-80/08.

Zoltai, S.C. and F.C. Pollett (1983) Wetlands in Canada: Their classification, distribution and use. In Mires: Swamp, Bog, Fen and Moor A.J.P. Gore (Ed.). Amsterdam: Elsevier Scientific. 
Public reporting burden for this collection of information is estimated to average 1 hour per response, including the time for reviewing instructions, searching existing data sources, gathering and maintaining the data needed, and completing and reviewing the collection of information. Send comments regarding this burden estimate or any other. aspect of this collection of information, including suggestion for reducing this burden, to Washington Headquarters Services, Directorate for Information Operations and Reports, 1215 Jefferson Davis Highway, Suite 1204, Arlington, VA 22202-4302, and to the Office of Management and Budget, Paperwork Reduction Project (0704-0188), Washington, DC 20503.

\begin{tabular}{|l|l|l|}
\hline $\begin{array}{l}\text { 1. AGENCY USE ONLY (Leave blank) } \\
\text { 2. REPORT DATE } \\
\text { August 1994 }\end{array}$ & 3. REPORT TYPE AND DATES COVERED \\
\hline
\end{tabular}

4. TITLE AND SUBTITLE

Current Issues in Alaska Wetland Management

6. AUTHORS

Charles H. Racine

7. PERFORMING ORGANIZATION NAME(S) AND ADDRESS(ES)

U.S. Army Cold Regions Research and Engineering Laboratory

72 Lyme Road

Hanover, N.H. 03755-1290

9. SPONSORING/MONITORING AGENCY NAME(S) AND ADDRESS(ES)

Office of the Chief of Engineers

5. FUNDING NUMBERS

Washington, D.C.

11. SUPPLEMENTARY NOTES

12a. DISTRIBUTION/AVAILABILITY STATEMENT

Approved for public release; distribution is unlimited.

Available from NTIS, Springfield, Virginia 22161

8. PERFORMING ORGANIZATION

REPORT NUMBER

Special Report 94-26

13. ABSTRACT (Maximum 200 words)

Although wetlands cover over half of Alaska, the status, management and regulation of these areas is problematic. The technical literature on Alaskan wetland vegetation, soils and hydrology is abundant, but the application of the literature to wetland management is poorly developed. This report identifies problems, issues and information gaps in the management of Alaskan wetlands. There are numerous arguments and debates on the designation, function and values, and disturbance of certain wetlands in Alaska. Permafrost, fire cycles and unique hydrologic regimes complicate the designation and delineation of Alaskan wetlands. The functions and values of most Alaskan wetlands clearly lie in their importance as habitat, particularly for migrating waterbirds, but an understanding of their role in flood water storage, water quality improvement, subsistence and other functions remains controversial and in need of study. Disturbance and other impacts on Alaskan wetlands is small relative to the large area that wetlands cover and in comparison with the loss of wetlands in the lower 48 states. However, several development projects in Alaska have affected large wetland areas and methods to restore these wetlands are being developed. Cumulative impacts are unknown, as are techniques for restoring permafrost wetlands containing gravel fill.

\begin{tabular}{|c|c|c|}
\hline $\begin{array}{c}\text { 14. SUBJECT TERMS } \\
\text { Alaska } \\
\text { Wetlands }\end{array}$ & \multicolumn{2}{c|}{ Wetland management } \\
$\begin{array}{c}\text { 17. SECURITY CLASSIFICATION } \\
\text { OF REPORT } \\
\text { UNCLASSIFIED }\end{array}$ & $\begin{array}{c}\text { 18. SECURITY CLASSIFICATION } \\
\text { OF THIS PAGE } \\
\text { UNCLASSIFIED }\end{array}$ & $\begin{array}{l}\text { 19. SECURITY CLASSIFICATION } \\
\text { OF ABSTRACT } \\
\text { UNCLASSIFIED }\end{array}$ \\
\hline
\end{tabular}

15. NUMBER OF PAGES 24

16. PRICE CODE

20. LIMITATION OF ABSTRACT

UL 